\title{
LMO2 wt Allele
}

National Cancer Institute

\section{Source}

National Cancer Institute. LMO2 wt Allele. NCI Thesaurus. Code C53033.

Human LMO2 wild-type allele is located in the vicinity of $11 \mathrm{p} 13$ and is approximately $34 \mathrm{~kb}$ in length. This allele, which encodes rhombotin-2 protein, is involved in red blood cell development through the modulation of transcription by RNA polymerase II. 